\title{
MicroRNAs are Emerging as Most Potential Molecular Biomarkers
}

\author{
Sanjay Yadav ${ }^{1 *}$, Abhishek Jauhari ${ }^{1,2}$, Nishant Singh ${ }^{1}$, Tanisha Singh ${ }^{1}$, Ankur Kumar Srivastav ${ }^{1,2}$, Parul Singh ${ }^{1}$, AB Pant $^{1}$ and Devendra Parmar ${ }^{1}$ \\ ${ }^{1}$ Developmental Toxicology Division, CSIR-Indian Institute of Toxicology Research, Lucknow, Mahatma Gandhi Marg, Lucknow, UP, India \\ ${ }^{2}$ Academy of Scientific and Innovative Research (AcSIR), India
}

Broadly biomarker word is defined as quantifiable indicator of disease conditions or physiological changes of living organisms. Biomarker field is very old, only few specific biochemical and molecular biomarkers are identified. Discovery of novel and specific biomarkers is still facing several challenges [1]. Based on the methods of quantification, biomarkers can be classified in three types 1) Imaging biomarkers (like X-ray, ultra sound, CT scan, PET, MRI), 2) Biochemical biomarkers (transaminases, bilirubin, alkaline phosphatase, serum creatinine) and 3) Molecular biomarkers. Molecular biomarkers are defined as markers which are measured based on genomic and proteomic approaches. Molecular biomarkers are most recent development in biomarker field, which is still in early developmental stage and needs tremendous amount of research to identify the specific biomarkers which can help in detection of disease before onset of physio; pathological changes or symptoms.

Discovery of small regulatory RNA molecules known as microRNAs (miRNAs), dramatically fasten the speed of development in the field of molecular biomarkers [2]. MiRNAs are small (around 20bp), non-protein coding RNA molecules, which controls protein synthesis in sequence specific manner [3]. Identification of miRNA expression in the circulating fluids including whole blood, serum, plasma, and other body fluids provides an opportunity to develop them as novel biomarkers. Identification of crucial regulatory role of miRNAs in almost every physiologial or cellular process, positions them ahead of other molecules in race for biomarkers [3-6]. Relatively higher halflife or stability of miRNAs in comparison to mRNAs probably due to their shorter size provides additional benefits in their detection and biomarker development [7]. Moreover, total number of identified miRNAs $(2000)$ is around $5 \%$ of total number of known protein coding mRNAs, so it is relatively easy to profile their expression. With rapid advancement in sequencing and expression profiling techniques, in future clinicians will be able to have look on global miRNA profiling data of patients before prescribing drugs to patients. Diseases like cancer and neurological disorders can be treated successfully if they are detected in their early phases. Both cancer and neurological disorders needs identification of reliable and early biomarkers based on changes which preceeds pathological symptoms of these diseases. Regulation of miRNAs and their target mRNAs provides best option for development of novel biomarkers in these diseases.

Pubmed is overfilled with research papers on identification of circulatory miRNAs in one or another disease and equally good number of reviews are also available compiling their details [8-11]. A summary of same have been provided in Tables 1 and 2. Studies of Yanaihara et al., seems to be first report, which described regulation of miRNA expression as indicator of lung cancer, for diagnostic and prognastic purposes [12]. Their studies have found that high miR-155 and low let7a-2 expression coorelates with poor survival in lung cancer patients [7]. Developing miRNA based biomarkers can also help in differntiating cancer types and stages of cancer development, which is a major issue in their treatment [10-13]. Interestingly miRNAs are also detected in microvesicles and exosomes, which act as communicator between cells [13-15]. As these extracellular vesicles are secreted from different kind of cells like cancer cells, lymphocytes, immune cells, dendritic cells, and regulation of miRNA expression in these cells can provide crucial information about molecular changes happening inside the tissue of origin. Most of the studies carried out on development of miRNA based biomarkers used blood or tissue samples from patients carrying disease [16]. However for identification of early biomarkers, studies are needed which involves expression kinetics of miRNAs between non-disease stage to disease stage. Long term studies, which involve unbiased expression profiling of miRNAs in large populations over long time can identify the miRNAs which are altered before onset of disease. In conclusion, miRNAs can act as better molecular biomarkers than existing biomarkers and development of specific biomarkers for cancer or neurological disorders will help in managing these diseases.

\begin{tabular}{|l|l|}
\hline MiRNA & Disease \\
\hline miR-21 & Breast cancer [17], Colorectal cancer [18], Gastric cancer [19]. \\
\hline miR-143 & $\begin{array}{l}\text { Non-small cell lung cancer [20], Bladder cancer [21], } \\
\text { colorectal cancer [22]. }\end{array}$ \\
\hline miR-375 & $\begin{array}{l}\text { Esophageal squamous cell carcinoma [23], Head and neck } \\
\text { squamous cell [24], Prostate cancer [25] }\end{array}$ \\
\hline miR-155 & $\begin{array}{l}\text { Colorectalcancer [26], Non-small cell lung cancer [27]breast cancer } \\
\text { [28], diffuse large B-cell lymphoma [29]. }\end{array}$ \\
\hline miR-125b & Breast cancer [30], HBV-positive hepatocellular carcinoma [31]. \\
\hline miR-107 & Esophageal cancer [32] \\
\hline miR-31 & Oral cancer [33] \\
\hline miR-141 & Colon cancer [34] \\
\hline miR-184 & Squamous cell carcinoma of tongue [35] \\
\hline miR-17 & Nasopharyngeal carcinoma [36] lung cancer [37] \\
\hline miR-92 & Acute leukemia [38], breast cancer [39] \\
\hline miR-18a & Colorectal cancer [40] \\
\hline miR-18b & Rectal Cancer [41]. \\
\hline miR-20a & Rectal Cancer [41], nasopharyngeal carcinoma [36]. \\
\hline miR-218 & Gastric cancer [19], Colorectal cancer [42] \\
\hline $\begin{array}{l}\mathrm{m} ~ \mathrm{i} \text { R } \\
\text { 196a/b }\end{array}$ & Oral cancer [43]. \\
\hline miR-10b & Breast cancer [44], Oral cancer [45]. \\
\hline miR-221 & Colorectal cancer [46], Pancreatic cancer [47]. \\
\hline miR-181 & Breast cancer [48] \\
\hline miR-126 & T-cell leukemia [49]. \\
\hline
\end{tabular}

Table 1: List of miRNAs targeted as biomarker in different type of cancers

*Corresponding author: Sanjay Yadav, Developmental Toxicology Division, CSIR-Indian Institute of Toxicology Research, Lucknow, Mahatma Gandhi Marg, Lucknow, UP, India, Tel: +91-522-2613357*223; Fax: +91-5222628227; E-mail: sanjayitrc@gmail.com, sanjay@iitr es.in

Received: May 06, 2015; Accepted: June 10, 2015; Published June 12, 2015

Citation: Yadav S, Jauhari A, Singh N, Singh T, Srivastav AK, et al. (2015) MicroRNAs are Emerging as Most Potential Molecular Biomarkers. Biochem Anal Biochem 4: 191. doi:10.4172/2161-1009.1000191

Copyright: @ 2015 Yadav S, et al. This is an open-access article distributed under the terms of the Creative Commons Attribution License, which permits unrestricted use, distribution, and reproduction in any medium, provided the original author and source are credited. 


\section{Alzhimer's Disease}

miR-112, miR-161, let-7d-3p, miR-5010-3p, miR-26a-5p, miR-1285-5p, miR-151a-3p, miR-103a-3p, miR-107, miR-532-5p, miR-26b-5p, let-7f-5p References let-7f, miR-105, miR-125a, miR-135a, miR-138, miR-141, miR 151, miR-186, miR-191, miR-197, miR-204, miR-205, miR-216 miR-302b, miR-30a-5p, miR-30a-3p, miR-30b, miR-30c, miR-30d, miR-32, miR-345, miR-362, miR-371, miR-374, miR-375, miR-380 3p, miR-429, miR-448, miR-449, miR-494, miR-501, miR-517, miR 517b, miR-518b, miR-518f, miR-520a*, miR-526a

let-7d-5p, let-7g-5p, miR-15b-5p, miR-142-3p, miR-191-5p, miR$301 a-3 p$ and miR-545-3p

$\mathrm{miR}-125 \mathrm{~b}, \mathrm{miR}-181 \mathrm{c}$

miR-137, miR-181c, miR-9, miR-29a/b

miR-132 family(miR-128/miR-491-5p, miR-132/miR-491-5p, and mir-874/miR-491-5p) and miR-134 family (miR-134/miR-370, miR323-3p/miR-370, and miR-382/miR-370)

\section{Parkinson's Disease}

miR-1, miR-22*, miR-29a

miR-1826, miR-450b-3p, miR-626, and miR-505

作

125a-3p, miR-137

miR-19b, miR-29a miR-29c

\section{Multiple Sclerosis}

miR-18b, miR-493, miR-599

miR-614, miR-572, miR- 648, miR-1826, miR-422a, miR-22, miR-1979

miR-922, miR-181c, miR-633

miR-223, miR-23a and miR-15b

Table 2: List of miRNAs targeted as biomarker in different neurodegenrative disorders.

\section{Conflict of Interest}

The authors declare no conflict of interest.

\section{Acknowledgements}

Abhishek Jauhari is grateful to CSIR, New Delhi and UGC, New Delhi respectively for providing Research Fellowship. Financial support for carrying out research work in our laboratory was provided by miND, InDepth \& nanoSHE (CSIR network projects) and GAP221 \& GAP254 (Funded by DBT, New Delhi).

\section{References}

1. McDermott JE, Wang J, Mitchell H, Webb-Robertson BJ, Hafen R, et al. (2013) Challenges in Biomarker Discovery: Combining Expert Insights with Statistical Analysis of Complex Omics Data. Expert Opin Med Diagn 7: 37-51.

2. Berindan-Neagoe I, Monroig Pdel C, Pasculli B, Calin GA (2014) MicroRNAome genome: a treasure for cancer diagnosis and therapy. CA Cancer J Clin 64: 311-336.

3. Bartel DP (2009) MicroRNAs: target recognition and regulatory functions. Cell 136: $215-233$

4. Singh T, Jauhari A, Pandey A, Singh P, Pant AB, et al. (2014) Regulatory triangle of neurodegeneration, adult neurogenesis and microRNAs. CNS Neurol Disord Drug Targets 13: 96-103.

5. Pandey A, Singh P, Jauhari A, Singh T, Khan F, et al. (2015) Critical role of the miR-200 family in regulating differentiation and proliferation of neurons. $J$ Neurochem 133: 640-652.

6. Yadav S, Pandey A, Shukla A, Talwelkar SS, Kumar A, et al. (2011) miR-497 and miR-302b regulate ethanol-induced neuronal cell death through BCL2 protein and cyclin D2. J Biol Chem 286: 37347-37357.

7. Gibbings DJ, Ciaudo C, Erhardt M, Voinnet O (2009) Multivesicular bodies associate with components of miRNA effector complexes and modulate miRNA activity. Nat Cell Biol 11: 1143-1149.

8. Chen M, Calin GA, Meng QH (2014) Circulating microRNAs as Promising Tumor Biomarkers. Adv Clin Chem 67: 189-214.
9. Allegra A, Alonci A, Campo S, Penna G, Petrungaro A, et al. (2012) Circulating microRNAs: new biomarkers in diagnosis, prognosis and treatment of cancer (review). Int J Oncol 41: 1897-1912.

10. Kim TH, Song JY, Park H, Jeong JY, Kwon AY, et al. (2015) miR-14, targeting high-mobility group $A$, is a powerful predictor of patient outcome in ovarian carcinoma. Cancer Lett 356: 937-945

11. Mishra PJ (2014) Non-coding RNAs as clinical biomarkers for cancer diagnosis and prognosis. Expert Rev Mol Diagn 14: 917-919.

12. Yanaihara N, Caplen N, Bowman E, Seike M, Kumamoto K, et al. (2006) Unique microRNA molecular profiles in lung cancer diagnosis and prognosis. Cancer Cell 9: 189-198.

13. Hunter MP, Ismail N, Zhang X, Aguda BD, Lee EJ, et al. (2008) Detection of microRNA expression in human peripheral blood microvesicles. PLoS One 3 : e3694.

14. Camussi G, Deregibus MC, Bruno S, Cantaluppi V, Biancone L (2010) Exosomes/microvesicles as a mechanism of cell-to-cell communication. Kidney Int 78: 838-848.

15. Michael A, Bajracharya SD, Yuen PS, Zhou H, Star RA, et al. (2010) Exosome from human saliva as a source of microRNA biomarkers. Oral Dis 16: 34-38.

16. Chen B, Tang H, Liu X, Liu P, Yang L, et al. (2015) miR-22 as a prognostic factor targets glucose transporter protein type 1 in breast cancer. Cancer Lett 356: 410-417.

17. Yan LX, Huang XF, Shao Q, Huang MY, Deng L, et al. (2008) MicroRNA miR-21 overexpression in human breast cancer is associated with advanced clinical stage, lymph node metastasis and patient poor prognosis. RNA 14: 2348-2360.

18. Toiyama Y, Takahashi M, Hur K, Nagasaka T, Tanaka K, et al. (2013) Serum miR-21 as a diagnostic and prognostic biomarker in colorectal cancer. J Nat Cancer Inst 105: 849-859.

19. Li BS, Zhao YL, Guo G, Li W, Zhu ED, et al. (2012) Plasma microRNAs, miR22, miR-21 and miR-218, as novel potential biomarkers for gastric cancer detection. PLoS One 7: e41629.

20. Gao W, Yu Y, Cao H, Shen H, Li X, et al. (2010) Deregulated expression of miR-, miR-143 and miR-181a in non small cell lung cancer is related to clinicopathologic characteristics or patient prognosis. Biomed Pharmacother 64: 399-408.

21. Puerta-Gil P, García-Baquero R, Jia AY, Ocaña $S$, Alvarez-Múgica $M$, et al. (2012) miR-1, miR-22, and miR-452 are useful as tumor stratification and noninvasive diagnostic biomarkers for bladder cancer. Am J Pathol 180: 1808-1815.

22. Li JM, Zhao RH, Li ST, Xie CX, Jiang HH, et al. (2012) Down-regulation of fecal miR-143 and miR-145 as potential markers for colorectal cancer. Saudi Med J 33: $24-29$.

23. Li J, Li X, Li Y, Yang H, Wang L, et al. (2013) Cell-specific detection of miR375 downregulation for predicting the prognosis of esophageal squamous cell carcinoma by miRNA in situ hybridization. PLoS One 8: e53582.

24. Harris T, Jimenez L, Kawachi N, Fan JB, Chen J, et al. (2012) Low-level expression of miR-375 correlates with poor outcome and metastasis while altering the invasive properties of head and neck squamous cell carcinomas. Am J Pathol 180: 917-928.

25. Huang X, Yuan T, Liang M, Du M, Xia S, et al. (2015) Exosomal miR-1290 and miR-375 as prognostic markers in castration-resistant prostate cancer. Eur Urol 67: 33-41.

26. Shibuya $H$, linuma $H$, Shimada $R$, Horiuchi A Watanabe $T$ (2010) Clinicopathological and prognostic value of microRNA-21 and microRNA-155 in colorectal cancer. Oncology 79: 313-320.

27. Yang M, Shen H, Qiu C, Ni Y, Wang L, et al. (2013) High expression of miR-21 and miR-155 predicts recurrence and unfavourable survival in non-small cell lung cancer. Eur J Cancer 49: 604-615.

28. Sun Y, Wang M, Lin G, Sun S, Li X, et al. (2012) Serum microRNA-155 as a potential biomarker to track disease in breast cancer. PLoS One 7: e47003.

29. Lawrie CH, Gal S, Dunlop HM, Pushkaran B, Liggins AP, et al. (2008) Detection of elevated levels of tumour-associated microRNAs in serum of patients with diffuse large B-cell lymphoma. British journal of haematology 141: 672-675.

30. Wang H, Tan G, Dong L, Cheng L, Li K, et al. (2012) Circulating MiR-125b as a marker predicting chemoresistance in breast cancer. PLoS One 7: e34210. 
Citation: Yadav S, Jauhari A, Singh N, Singh T, Srivastav AK, et al. (2015) MicroRNAs are Emerging as Most Potential Molecular Biomarkers. Biochem Anal Biochem 4: 191. doi:10.4172/2161-1009.1000191

Page 3 of 3

31. Giray BG, Emekdas G, Tezcan S, Ulger M, Serin MS, et al. (2014) Profiles of serum microRNAs; miR-125b-5p and miR223-3p serve as novel biomarkers for HBV-positive hepatocellular carcinoma. Molecular biology reports 41: 45134519.

32. Sharma P, Saraya A, Gupta P, Sharma R (2013) Decreased levels of circulating and tissue miR-107 in human esophageal cancer. Biomarkers 18: 322-330.

33. Liu CJ, Kao SY, Tu HF, Tsai MM, Chang KW, et al. (2010) Increase of microRNA miR-31 level in plasma could be a potential marker of oral cancer. Oral Dis 16: 360-364.

34. Cheng H, Zhang L, Cogdell DE, Zheng H, Schetter AJ, et al. (2011) Circulating plasma MiR-141 is a novel biomarker for metastatic colon cancer and predicts poor prognosis. PLoS One 6: e17745.

35. Wong TS, Liu XB, Wong BY, Ng RW, Yuen AP, et al. (2008) Mature miR-184 as Potential Oncogenic microRNA of Squamous Cell Carcinoma of Tongue. Clin Cancer Res 14: 2588-2592.

36. Zeng X, Xiang J, Wu M, Xiong W, Tang H, et al. (2012) Circulating miR-17, miR-20a, miR-29c, and miR-223 combined as non-invasive biomarkers in nasopharyngeal carcinoma. PLoS One 7: e46367.

37. Chen Q, Si Q, Xiao S, Xie Q, Lin J, et al. (2013) Prognostic significance of serum miR-17-5p in lung cancer. Med Oncol 30: 353

38. Tanaka M, Oikawa K, Takanashi M, Kudo M, Ohyashiki J, et al. (2009) Downregulation of miR-92 in human plasma is a novel marker for acute leukemia patients. PLoS One 4: e5532.

39. Si H, Sun X, Chen Y, Cao Y, Chen S, et al. (2013) Circulating microRNA-92a and microRNA-21 as novel minimally invasive biomarkers for primary breast cancer. J Cancer Res Clin Oncol 139: 223-229.

40. Brunet Vega A, Pericay C, Moya I, Ferrer A, Dotor E, et al. (2013) microRNA expression profile in stage III colorectal cancer: circulating miR-18a and miR29a as promising biomarkers. Oncol Rep 30: 320-326.

41. Azizian A, Kramer F, Jo P, Wolff HA, Beißbarth T, et al. (2015) Preoperative Prediction of Lymph Node Status by Circulating Mir-18b and Mir-20a During Chemoradiotherapy in Patients with Rectal Cancer. World J Surg

42. Yu H, Gao G, Jiang L, Guo L, Lin M, et al. (2013) Decreased expression of miR218 is associated with poor prognosis in patients with colorectal cancer. Int J Clin Exp Pathol 6: 2904-2911.

43. Lu YC, Chang JT, Huang YC, Huang CC, Chen WH, et al. (2015) Combined determination of circulating miR-196a and miR-196b levels produces high sensitivity and specificity for early detection of oral cancer. Clin Biochem 48 : 115-121.

44. Chen W, Cai F, Zhang B, Barekati Z, Zhong XY (2013) The level of circulating miRNA-10b and miRNA-373 in detecting lymph node metastasis of breast cancer: potential biomarkers. Tumour Biol 34: 455-462.

45. Lu YC, Cheng AJ (2011) Profiling of microRNA in oral cancer cells identifying miR-10b functions in oncogenesis and up-regulates in plasma of oral cancer patients. Cancer Research 71: 162-162.

46. Pu XX, Huang GL, Guo HQ, Guo CC, Li H, et al. (2010) Circulating miR-221 directly amplified from plasma is a potential diagnostic and prognostic marker of colorectal cancer and is correlated with p53 expression. J Gastroenterol Hepatol 25: 1674-1680
47. Kawaguchi T, Komatsu S, Ichikawa D, Morimura R, Tsujiura M, et al. (2013) Clinical impact of circulating miR-221 in plasma of patients with pancreatic cancer. Br J Cancer 108: 361-369.

48. Guo LJ, Zhang QY (2012) Decreased serum miR-181a is a potential new too for breast cancer screening. Int J Mol Med 30: 680-686.

49. Ishihara K, Sasaki D, Tsuruda K, Inokuchi N, Nagai K, et al. (2012) Impact of miR-155 and miR-126 as novel biomarkers on the assessment of disease progression and prognosis in adult T-cell leukemia. Cancer Epidemiol 36: 560-565.

50. Alexandrov PN, Dua P, Hill JM, Bhattacharjee S, Zhao Y, et al. (2012) microRNA (miRNA) speciation in Alzheimer's disease (AD) cerebrospinal fluid (CSF) and extracellular fluid (ECF). Int J Biochem Mol Biol 3: 365-373.

51. Leidinger P, Backes C, Deutscher S, Schmitt K, Mueller SC, et al. (2013) A blood based 12-miRNA signature of Alzheimer disease patients. Genome Biol 14: R78.

52. Cogswell JP, Ward J, Taylor IA, Waters M, Shi Y, et al. (2008) Identification of miRNA changes in Alzheimer's disease brain and CSF yields putative biomarkers and insights into disease pathways. J Alzheimers Dis 14: 27-41.

53. Kumar P, Dezso Z, MacKenzie C, Oestreicher J, Agoulnik S, et al. (2013) Circulating miRNA biomarkers for Alzheimer's disease. PLoS One 8: e69807.

54. Tan L, Yu JT, Liu QY, Tan MS, Zhang W, et al. (2014) Circulating miR-125b as a biomarker of Alzheimer's disease. J Neurol Sci 336: 52-56.

55. Sheinerman KS, Tsivinsky VG, Crawford F, Mullan MJ, Abdullah L, et al. (2012) Plasma microRNA biomarkers for detection of mild cognitive impairment. Aging (Albany NY) 4: 590.

56. Margis R, Margis R, Rieder CR (2011) Identification of blood microRNAs associated to ParkinsonÄs disease. J Biotechnol 152: 96-101.

57. Khoo SK, Petillo D, Kang UJ, Resau JH, Berryhill B, et al. (2012) Plasma-based circulating MicroRNA biomarkers for Parkinson's disease. J Parkinsons Dis 2 : 321-331.

58. Cardo LF, Coto E, de Mena L, Ribacoba R, Moris G, et al. (2013) Profile of microRNAs in the plasma of Parkinson's disease patients and healthy controls. J Neurol 260: 1420-1422.

59. Botta-Orfila T, Morató X, Compta Y, Lozano JJ, Falgàs N, et al. (2014) Identification of blood serum micro-RNAs associated with idiopathic and LRRK2 Parkinson's disease. J Neurosci Res 92: 1071-1077.

60. Otaegui D, Baranzini SE, Armañanzas R, Calvo B, Muñoz-Culla M, et al. (2009) Differential micro RNA expression in PBMC from multiple sclerosis patients. PLoS One 4: e6309.

61. Siegel SR, Mackenzie J, Chaplin G, Jablonski NG, Griffiths L (2012) Circulating microRNAs involved in multiple sclerosis. Mol Biol Rep 39: 6219-6225.

62. Haghikia A, Haghikia A, Hellwig K, Baraniskin A, Holzmann A, et al. (2012) Regulated microRNAs in the CSF of patients with multiple sclerosis: a casecontrol study. Neurology 79: 2166-2170.

63. Ridolfi E, Fenoglio C, Cantoni C, Calvi A, De Riz M, et al. (2013) Expression and Genetic Analysis of MicroRNAs Involved in Multiple Sclerosis. Int J Mol Sci 14: $4375-4384$. 